\title{
PENGARUH DUKUNGAN ENDORSER DAN BRAND FAMILIARITY TERHADAP PERCEPTION OF PURCHASE RISK DAN DAMPAKNYA PADA NIAT BELI PRODUK BRAND EXTENSION
}

\author{
Lialutfi Mayangsari \\ E-mail: mayalutfi08@gmail.com \\ Y. Lilik Rudianto \\ Departemen Manajemen Fakultas Ekonomi dan Bisnis Universitas Airlangga
}

\begin{abstract}
At this time, the firms faced tight competition. The firms expected to manage the resources possessed to be able to win the competition. One method used to develop the brand with the expansion of related or unrelated to the parent brand. This strategy is done by utilizing the parent brand advertising campaign media. In the advertising, usually raises the figure endorser such as a celebrityor not to display the endorser with a familiar brand or unfamiliar brand. By looking at the ads with display support different endorser and brands make different consumer response to the perception of risk purchase that ultimately led to purchase intention the product extension.

This study was conducted to investigate the effect of endorser support and brand familiarity to perception of purchase risk and its impact on purchase intention of brand extension products. This study tried to see the main effect of the variables and its interactions with the effect that using a factorial experimental design 2 (endorser support) $\times 2$ (brand familiarity) with between subject methods. Data were obtained from 120 respondents who are students of SI Management Faculty of Economics and Business, University of Airlangga.

The analysis showed that there were no significant difference from the endorser support and there are significant differences from the brand familiarity on perception of purchase risk and there is no interaction effect between the endorser support and brand familiarity for reduces the perception of risk perceived by consumers. Perception of risk purchase also significantly influence consumer purchase intentions on the product brand extension.
\end{abstract}

Keywords : endorser, brand familiarity, perception of purchase risk, purchase intention.

\section{PENDAHULUAN}

Kondisi pemasaran di era modern ini semakin dinamis dan berkembang dengan pesat, hal ini menyebabkan kompetisi antar perusahaan semakin ketat dalam menjual dan memasarkan produknya. Berbagai upaya dilakukan tidak hanya dalam meningkatkan kualitas produk, diferensiasi produk dan inovasi teknologi dalam proses produksinya melainkan juga dengan penciptaan merek yang unggul atas suatu produk. Salah satu cara 


\section{Lialutfi Mayangsari \\ Y. Lilik Rudianto}

yang dapat dilakukan adalah melakukan manajemen merek yang baik sehingga produk dapat diterima oleh konsumen. Kotler dan Keller (2009) menyebutkan bahwa merek menandakan suatu tingkat mutu tertentu, sehingga pembeli yang puas lebih mudah memilih produk yang diinginkan. Strategi yang bisa dilakukan oleh manajer dalam membangun dan me-leverage mereknya adalah dengan melakukan brand extension.

Di Indonesia ada beberapa perusahaan yang menerapkan strategi brand extension dengan kategori high similarity maupun low similarity. Salah satu perusahaan yang menerapkan strategi brand extension dengan kategori high similarity adalah PT. Unilever Indonesia Tbk dengan beberapa produknya yang tergolong dalam Fast Moving Consumer Goods (FMCG) seperti Lifebuoy dan Dove. Lifebuoy dengan merek yang sudah dikenal oleh konsumen sebagai sabun anti kuman diperluas dengan mengeluarkan kategori produk baru yaitu shampoo dan handwash. Sama halnya dengan merek produk Lifebuoy, merek produk Dove pun awalnya adalah produk sabun mandi yang kemudian diperluas dengan kategori shampoo. Merek produk Pepsodent sebagai merek pasta gigi pertama di Indonesia juga melakukan perluasan merek dengan masuk pada kategori produk cairan pembersih mulut dan permen (http://bisnisukm.com/).

Melihat kesuksesan dari penggunaan strategi brand extension yang ada pada perusahaan tersebut, ada beberapa merek yang melakukan strategi brand extension dengan kategori low similarity namun produk brand extension yang dihasilkan gagal setelah produk tersebut diluncurkan di pasar. Merek tersebut adalah Colgate yang merupakan merek asal Amerika Serikat ini pada tahun 1982 meluncurkan Kitchen Entrees sebagai bagian dari pengenalan produk makanan beku, dimana setelah itu muncul ide untuk mengeluarkan produk pasta gigi dengan harapan konsumen setelah menikmati hidangan akan membersihkan mulut mereka dan membeli produk pasta gigi dengan merek Colgates. Namun, setelah hal ini diterapkan maka terjadi asosiasi yang membingungkan dari konsumen tentang merek tersebut, Colgates dikaitkan dengan merek kebersihan dan perawatan mulut yang menyebabkan konsumennya menjadi tidak tertarik untuk membeli makanan yang mereknya sama dengan merek pasta gigi (Haig, 2003)

Berdasarkan fenomena tersebut dapat dilihat bahwa brand extension dengan kategori high similarity lebih mudah mengalami kesuksesan dikarenakan merupakan hal yang wajar kerena sesuai dari core kompetensi dari merek tersebut, sehingga penelitian ini melakukan skenario brand extension dengan kategori low similarity untuk mengetahui faktorfaktor yang dapat mendukung kesuksesan strategi tersebut.

Produk brand extension dengan kategori low similarity membutuhkan piecemeal processing dan exstrinsic cues yang tidak secara langsung berhubungan dengan produk (Boush dan Loken, 1991; Yeo dan Park, 2006). Exstrinsic cues berupa iklan dapat mengkomunikasikan pesan secara langsung kepada konsumen. Pada iklan biasanya 
terdapat peripheral cues yang berfungsi sebagai dukungan dalam proses evaluasi dari konsumen. Peripheral cues yang digunakan adalah seorang endorser.

Seorang endorser mempunyai tujuan untuk menciptakan asosiasi yang baik antara endorser dengan produk yang diiklankan hingga timbul sikap positif dalam diri konsumen, sehingga iklan tersebut dapat menciptakan citra yang baik pula di mata konsumen (Temporal dan Lee, 2001). Choi dan Rifon (2007) menjelaskan bahwa endorser yang paling sering digunakan untuk produk ritel adalah celebrity endorser. Adanya celebrity endorser diharapkan dapat memiliki dampak positif pada konsumen dalam mengingat suatu merek karena adanya faktor yang dimiliki seperti daya tarik fisik, sumber kredibilitas, kongruensi maupun keandalan dari endorser. Memunculkan celebrity yang sering digunakan dalam komunikasi pemasaran juga dapat meningkatkan persepsi dari kualitas produk brand extension yang akhirnya akan mempengaruhi niat beli (Sattler dkk., 2010).

Kegiatan endorsment juga sering muncul pada iklan dengan merek - merek yang sudah familiar oleh konsumen dan ada pula merek yang belum dikenal baik oleh konsumen. Hal ini sesuai dengan tujuan dari iklan sendiri yaitu membangun preferensi merek atau mendidik orang (Kotler dan Keller, 2012:504). Ekspose dari media iklan akan meningkatkan brand familiarity sehingga mengurangi kebutuhan untuk mencari informasi yang lebih luas dan penelitian terdahulu menemukan bahwa konsumen cenderung lebih sedikit menghabiskan waktunya dalam mencari informasi tentang merek yang baik dikenal (familiar) dibandingkan dengan merek yang tidak terlalu baik dikenal (unfamiliar) (Hoch dan Deighton, 1989).

Penelitian ini menggunakan selebriti yang familiar untuk mengurangi dampak risiko pembelian ketika selebriti tersebut memiliki reputasi yang baik dan kredibilitas yang tinggi (e.g., Goldsmith dkk, 2000; Lafferty dan Goldsmith, 1999). Selain itu, parent brand familiarity dapat mengurangi risiko perluasan merek dan berpengaruh terhadap peningkatan nilai dari brand extension (Aaker dan Keller, 1991). Pada beberapa penelitian, menyatakan bahwa adanya dukungan dari selebriti akan memberikan dampak positif pada niat beli konsumen (Goldsmith dkk., 2000). Menurut Kotler dan Amstrong (2013:177) mengatakan bahwa pada tahap evaluasi, konsumen menggolongkan suatu merek dan membentuk niat beli. Secara umum, keputusan pembelian yang dilakukan oleh konsumen akan digunakan untuk membeli merek yang paling disukai.

\section{Rumusan Masalah}

1. Apakah terdapat perbedaan perception of purchase risk pada produk brand extension berdasarkan dukungan endorser ?

2. Apakah terdapat perbedaan perception of purchase risk pada produk brand extension berdasarkan adanya brand familiarity? 


\section{Lialutfi Mayangsari \\ Y. Lilik Rudianto}

3. Apakah terdapat interaksi antara dukungan endorser dan brand familiarity dalam menurunkan perception of purchase risk pada produk brand extension?

4. Apakah perception of purchase risk berpengaruh negatif terhadap niat beli dari produk brand extension?

\section{Tujuan Penelitian}

1. Mengetahui perbedaan perception of purchase risk pada produk brand extension berdasarkan dukungan endorser

2. Mengetahui perbedaan perception of purchase risk pada produk brand extension yang dirasakan konsumen berdasarkan adanya brand familiarity

3. Mengetahui hubungan interaksi antara dukungan endorser dan brand familiarity terhadap perception of purchase risk pada produk brand extension

4. Mengetahui pengaruh perception of purchase risk terhadap niat beli dari produk brand extension

\section{LANDASAN TEORI}

\section{Brand Extension}

Pada dasarnya brand extension adalah penggunaan nama merek yang sudah mapan untuk memasuki kategori produk yang lain (Keller, 2008). Tujuan perusahaan menggunakan strategi ini adalah untuk me-leverage aset yang dimilikinya dengan mengenalkan produk baru dari adanya kekuatan merek yang ada (Kotler dan Keller, 2012:285). Strategi brand extension dapat dikatakan "bagus" ketika parent brand dapat membantu produk brand extensionnya untuk sukses di pasar, dan dapat dikatakan "sangat bagus" ketika produk brand extensionnya juga mampu membantu kesuksesan dari parent brand.

\section{Brand Familiarity}

Definisi brand familiarity berdasarkan Alba dan Hutchinson (1987) adalah seberapa besar merek berkaitan secara langsung maupun tidak langsung dengan pengalaman yang dimiliki oleh konsumen. Pengalaman dari merek sendiri dapat didapatkan dari ekspose media periklanan tentang merek tersebut, ekspose merek pada suatu toko, dan pembelian atau penggunaan merek yang dapat meningkatkan brand familiarity. Lebih jauh, pada perilaku merek biasanya menggunakan terminologi seperti keakraban, pengetahuan, dan pengalaman yang mampu menjelaskan gagasan tentang brand familiarity tersebut (Tam, 2008). Sebuah merek dikatakan memiliki kedekatan yang tinggi apabila konsumen mengenal dengan baik (familiar) merek tersebut, dan sebaliknya suatu konsumen dikatakan memiliki kedekatan rendah apabila konsumen tidak baik mengenal merek tersebut (unfamiliar) (Kusumasondjaja, 2014). Dalam konteks brand extension, sebuah merek yang 
sudah dikenal baik akan bertindak sebagai pengurang risiko dan meningkatkan kemungkinan dari mencoba pembelian produk baru (Thamaraiselvan dan Raja, 2008).

\section{Endorser}

Definisi endorser berdasarkan pernyataan dari Belch dan Belch (2012:180) adalah seseorang atau figur yang terlibat dalam komunikasi pemasaran yang berfungsi untuk menyampaikan suatu pesan kepada konsumen baik secara langsung maupun tidak langsung. celebrity endorser adalah setiap individu yang menikmati pengakuan publik dan menggunakan pengakuan ini atas nama seorang konsumen yang baik untuk muncul dalam sebuah iklan. Berdasarkan model distribusi makna, celebrity endorser juga memberikan arti dan citra positif terhadap iklan sekaligus mengkomunikasikannya pada produk yang diiklankan.

\section{Percieve Risk}

Persepsi risiko itu sendiri didefinisikan sebagai tingkat ketidakpastian yang dipersepsikan oleh konsumen dalam menentukan sebuah keputusan pembelian tertentu (Biswas dkk., 2006). Persepsi risiko juga menunjukkan kemungkinan ketidaknyamanan dan ketidakyakinan serta tingkat kerugian yang ditanggung konsumen. Kebanyakan orang percaya bahwa merek yang sudah dikenal baik oleh konsumen dapat mengurangi risiko dan mempertinggi kemungkinan konsumen untuk mencoba.

\section{Niat Beli}

Menurut Kotler dan Keller (2012) niat beli adalah suatu ketertarikan konsumen pada sebuah merek produk sehingga dapat menimbulkan suatu keinginan membeli dan menimbulkan suatu tindakan membeli produk yang telah diinformasikan. Keputusan pembelian terdiri dari lima tahap yaitu pengenalan kebutuhan, pencarian informasi, evaluasi alternatif, keputusan pembelian dan perilaku pasca pembelian.

1. Tahap pengenalan kebutuhan

Proses pembelian dimulai dengan pengenalan kebutuhan (need recognition), pembeli menyadari suatu masalah atau kebutuhan. Kebutuhan dapat dipicu oleh rangsangan internal ketika salah satu kebutuhan normal seseorang: rasa lapar, haus, sex timbul pada tingkat yang cukup tinggi sehingga menjadi sebuah dorongan.

2. Tahap pencarian informasi

Konsumen yang tertarik mungkin mencari lebih banyak informasi atau mungkin tidak. Jika dorongan konsumen itu kuat dan produk yang memuaskan ada di dekat konsumen, konsumen mungkin akan membelinya. Jika tidak, konsumen bisa menyimpan kebutuhan itu dalam ingatannya atau melakukan pencarian informasi.

3. Tahap evaluasi alternatif

Evaluasi alternatif yaitu bagaimana konsumen memproses informasi untuk sampai pada pilihan merek. Konsumen sampai pada sikap terhadap merek yang berbeda melalui 


\section{Lialutfi Mayangsari \\ Y. Lilik Rudianto}

beberapa prosedur evaluasi, dalam beberapa kasus, konsumen menggunakan kalkulasi yang cermat dan pemikiran logis.

4. Tahap keputusan pembelian

Pada umumnya, keputusan pembelian konsumen adalah membeli merek yang paling disukai. Tetapi dua faktor bisa berada antara niat pembelian dan keputusan pembelian. Faktor pertama adalah sikap orang lain dan faktor kedua adalah faktor situasional yang tidak diharapkan.

5. Tahap perilaku pasca pembelian

Setelah membeli produk, konsumen akan merasa puas atau tidak puas dan terlibat dalam perilaku pasca pembelian yang harus diperhatikan oleh pemasar. Jika produk tidak memenuhi ekspektasi maka konsumen akan merasa kecewa, sebalikmya apabila produk telah memenuhi ekspektasi maka konsumen akan merasa puas.

\section{PENGEMBANGAN HIPOTESIS}

Seorang endorser mempunyai tujuan untuk menciptakan asosiasi yang baik antara endorser dengan produk yang diiklankan hingga timbul sikap positif dalam diri konsumen, sehingga iklan tersebut dapat menciptakan citra yang baik pula di mata konsumen (Temporal dan Lee, 2001). Dalam iklan biasanya menggunakan celebrity endorser untuk sebuah merek (misalnya pada parent brand sebagai produk perluasan potensial) yang dapat menawarkan strategi alternatif untuk menyampaikan extrinsic cues kepada konsumen guna meningkatkan potensi perluasan merek (Erfgen dkk., 2014). Hal ini disebabkan karena selebriti yang familiar dapat menurunkan persepsi risiko ketika mereka menikmati reputasi yang baik, level kredibilitas yang tinggi, dan menawarkan sinyal dari kualitas produk (Aakah dan Korgaonkar dalam Erfgen dkk., 2014). Dapat dikatakan bahwa iklan dengan dukungan endorser memiliki peran penting dalam aktivitas pengurangan persepsi risiko dibandingkan tidak terdapat dukungan endorser (no endorser). Hal ini karena kurangnya sikap positif terhadap iklan, rendahnya informasi dan kurang adanya sinyal terhadap kualitas produk sehingga persepsi risiko dalam melakukan pembelian akan semakin tinggi.

\section{H1 : Terdapat perbedaan yang signifikan pada perception of purchase risk berdasarkan dukungan endorser dimana perception of purchase risk akan lebih rendah apabila memunculkan dukungan endorser berupa celebrity endorser dibandingkan dengan tanpa dukungan endorser (no endorser).}

Pada penelitian yang dilakukan oleh Heilman dkk., (2000) tentang evolusi preferensi konsumen pada suatu kategori produk tertentu dari waktu ke waktu, diperoleh hasil bahwa pembeli yang kurang berpengalaman lebih memilih untuk merek - merek yang sudah akrab 
(familiar) dengan suatu kategori tertentu karena mereka memiliki persepsi bahwa produk tersebut tidak berisiko. Dengan adanya brand familiarity juga akan mengurangi kebutuhan untuk mencari informasi yang lebih luas dan peneliti menemukan bahwa konsumen cenderung lebih sedikit menghabiskan waktunya dalam mencari informasi tentang merek yang baik dikenal (familiar) dibandingkan dengan merek yang tidak terlalu baik dikenal (unfamiliar) (Hoch dan Deighton, 1989 dalam Perera dkk., 2013).

H2 : Terdapat perbedaan yang signifikan pada perception of purchase risk berdasarkan brand familiarity dimana perception of purchase risk akan lebih rendah apabila memunculkan merek yang familiar dibandingkan merek yang unfamiliar

Selebriti yang familiar dapat menurunkan persepsi risiko ketika mereka menikmati reputasi yang baik, level kredibilitas yang tinggi, dan menawarkan sinyal dari kualitas produk (Aakah dan Korgaonkar dalam Erfgen dkk., 2014). Selain itu, sebuah merek yang sudah dikenal baik akan bertindak sebagai pengurang risiko dan meningkatkan kemungkinan untuk mencoba pembelian produk baru (Thamaraiselvan dan Raja, 2008). Berdasarkan penelitian yang dilakukan oleh Baker dkk., (1987) mengemukakan bahwa ketika sebuah merek sudah familiar dengan konsumen melalui ekspose yang berulang - ulang maka persepsi risiko yang dirasakan konsumen akan semakin berkurang dan meningkatkan sikap yang baik terhadap produk.

H3 : Terdapat pengaruh interaksi yang signifikan antara dukungan endorser dan brand familiarity dimana interaksi antara celebrity endorserdanmerek yang familiarakan menimbulkan perception of purchase risk yang lebih rendah dibandingkan dengan interaksi lainnya.

Dalam konteks brand extension, perluasan merek dengan kategori low similarity dari parent brand sangat berisiko dan menyebabkan tingkat kegagalan yang tinggi (Aaker dan Keller, 1990 dalam Erfgen dkk., 2014). Persepsi risiko juga menunjukkan kemungkinan ketidaknyamanan dan ketidakyakinan serta tingkat kerugian yang ditanggung konsumen. Berdasarkan pemaparan tersebut dapat diprediksi bahwa persepsi risiko memiliki hubungan negatif dengan niat beli, karena ketika seseorang konsumen mempersepsikan risiko lebih besar dalam mengevaluasi suatu produk maka niat pembelian tidak akan terjadi (Hadianingtyas, 2013)

H4 : Perception of purchase risk memiliki pengaruh negatif terhadap niat beli

\section{METODE PENELITIAN}

Penelitian ini menggunakan pendekatan penelitian kuantitatif dengan metode eksperimen sedangkan jenis penelitian adalah kausal. Dalam penelitian ini dibedakan menjadi 2 variabel yakni (1) variabel bebas: dukungan endorser yang dibedakan menjadi celebrity endorser, no endorser serta brand familiarity yang dibedakan menjadi familiar dan unfamiliar 


\section{Lialutfi Mayangsari \\ Y. Lilik Rudianto}

(2) variabel terikat yaitu perception of purchase risk dan niat beli. Definisi operasional adalah sebagai berikut:

\section{a. Endorser}

Seseorang atau figur yang terlibat dalam komunikasi pemasaran yang berfungsi untuk menyampaikan suatu pesan kepada konsumen baik secara langsung maupun tidak langsung. Mengadaptasi penelitian dari Erfgen dkk., (2014) dukungan endorser dibedakan menjadi 2 yaitu :

1. Celebrity Endorser (X1). Berdasarkan pernyataan dari McCracken (1989), celebrity endorser adalah setiap individu yang menikmati pengakuan publik dan menggunakan pengakuan ini atas nama seorang konsumen yang baik untuk muncul dalam sebuah iklan. Celebrity endorser yang dimaksud dalam penelitian ini adalah artis yang menjadi bintang iklan dalam sebuah iklan. Pada penelitian ini, celebrity endorser yang digunakan adalah artis pemain film dan model yang penentuannya berdasarkan hasil pre-eliminary test.

2. No endorser (X2) adalah iklan yang ditampilkan tanpa menggunakan dukungan endorser. Dalam iklan tersebut hanya terdapat logo, gambar produk dan tagline.

\section{b. Brand Familiarity}

Definisi brand familiarity berdasarkan Alba dan Hutchinson (1987) adalah seberapa besar merek memiliki kedekatan secara langsung maupun tidak langsung dengan pengalaman yang dimiliki oleh konsumen. Dalam penelitian ini brand familiarity dibedakan menjadi dua yaitu :

1. Familiar. Merek yang familiar dalam penelitian ini adalah merek yang dikenal baik oleh konsumen. Artinya, konsumen mengetahui merek tersebut meskipun tidak menggunakannya.

2. Unfamiliar. Merek yang unfamiliar dalam penelitian ini adalah merek yang tidak dikenal baik oleh konsumen. Artinya, konsumen tidak mengetahui merek tersebut dan tidak menggunakannya.

\section{c. Perception of purchase risk}

Persepsi risiko itu sendiri didefinisikan sebagai tingkat ketidakpastian yang dipersepsikan oleh konsumen dalam menentukan sebuah keputusan pembelian tertentu (Biswas dkk., 2006) yaitu produk perluasan yang dikeluarkan oleh parent brandnya berupa pengharum ruangan.

\section{d. Niat Beli}

Niat beli merupakan kecenderungan konsumen untuk membeli produk tertentu (Belch and Belch, 2004) yaitu produk perluasan yang dikeluarkan oleh parent brandnya berupa pengharum ruangan. 
Pengumpulan data dilakukan melalui penyebaran kuesioner pada 120 orang mahasiswa Manajemen Fakultas Ekonomi dan Bisnis Universitas Airlangga. Teknik pengambilan sampel yang digunakan adalah convenience sampling dengan desain faktorial $2 \times 2$ sehingga setiap partisipan hanya mendapat satu kondisi perlakuan. Skala pengukuran yaitu dengan menggunakan 5 skala likert $(5=$ sangat setuju, $4=$ setuju, $3=$ netral, 2 = tidak setuju, 1 = sangat tidak setuju). Teknik analisis yang digunakan dalam penelitian ini adalah two way ANOVA dan regresi linier sederhana.

\section{HASIL DAN PEMBAHASAN}

\begin{tabular}{|c|l|c|}
\hline No & \multicolumn{1}{|c|}{ Hipotesis } & Hasil \\
\hline 1 & $\begin{array}{l}\text { Terdapat perbedaan yang signifikan perception of } \\
\text { purchase risk berdasarkan dukungan endorser dimana } \\
\text { Perception of purchase risk akan lebih rendah apabila } \\
\text { memunculkan dukungan endorser berupa celebrity } \\
\text { endorser dibandingkan dengan tanpa dukungan } \\
\text { endorser (no endorser). }\end{array}$ & \\
\hline 2 & $\begin{array}{l}\text { Terdapat perbedaan yang signifikan perception of } \\
\text { purchase risk berdasarkan brand familiarity dimana } \\
\text { Perception of purchase risk akan lebih rendah apabila } \\
\text { memunculkan merek yang familiar dibandingkan } \\
\text { merek yang unfamiliar }\end{array}$ & Diterima \\
\hline 4 & $\begin{array}{l}\text { Terdapat pengaruh interaksi yang signifikan antara } \\
\text { dukungan endorser dan brand familiarity dimana } \\
\text { Interaksi antara celebrity endorser dan merek yang } \\
\text { familiar akan menimbulkan perception of purchase risk } \\
\text { yang lebih rendah dibandingkan dengan interaksi } \\
\text { lainnya. }\end{array}$ & \\
\hline $\begin{array}{l}\text { Perception of purchase risk memiliki hubungan negatif } \\
\text { terhadap niat beli }\end{array}$ & Ditolak \\
\hline
\end{tabular}

\section{PEMBAHASAN}

Hubungan dukungan endorser terhadap Perception of Purchase Risk pada produk perluasan merek

Hasil pengujian yang dilakukan menunjukkan bahwa perbedaan dukungan endorser yang ditampilkan dalam iklan tidak memiliki pengaruh yang berbeda terhadap perception 


\section{Lialutfi Mayangsari \\ Y. Lilik Rudianto}

of purchase risk yang dirasakan oleh konsumen. Pengujian Two-Way ANOVA pada main effect tersebut menunjukkan hasil yang tidak signifikan. Hasil ini berbeda dengan penelitian sebelumnya yang dilakukan oleh Erfgen dkk., (2014) yang menyatakan bahwa celebrity endorser dapat menurunkan persepsi risiko dibandingkan dengan no endorser. Pada penelitian ini, responden menilai bahwa iklan yang memunculkan celebrity endorser maupun no endorser tidak berdampak pada persepsi risiko yang terlalu tinggi maupun rendah, meskipun jika dilihat dari rata-ratanya (mean) persepsi risiko pembelian yang dirasakan konsumen lebih rendah ketika memunculkan celebrity endorser dibandingkan dengan no endorser. Hal ini terjadi karena berdasarkan survey yang dilakukan terhadap 20 partisipan penelitian menunjukkan bahwa mereka semua mengenal dengan baik produk pengharum ruangan. Hal ini ditunjukkan dengan pernahnya melakukan transaksi pembelian dan mayoritas intensitas pembelian pada produk tersebut adalah satu kali dalam sebulan. Berdasarkan hasil survey dapat disimpulkan bahwa kelas produk pengharum ruangan yang diperluas oleh sabun mandi adalah produk yang telah lama beredar di pasar sehingga responden tidak menganggap pengharum ruangan merupakan produk yang berisiko tinggi. Hal ini mengakibatkan munculnya endorser dalam iklan tersebut tidak menimbulkan pengaruh yang berarti. Selain itu, hal ini didukung dengan pernyataan dari Keller (2008) tentang salah satu manfaat penggunaan strategi brand extension yang mana keuntungan memiliki merek yang sudah diketahui dan banyak disukai adalah konsumen memiliki ekspektasi yang tinggi dari kinerja merek tersebut, sehingga kualitas dari parent brand akan ditransfer pada produk perluasannya dan pada kasus ini kualitas dari produk pengharum ruangan juga berasal dari merek parent brandnya sehingga adanya endorser ataupun tidak akan kurang diperhatikan oleh konsumen.

\section{Hubungan brand familiarity terhadap Perception of Purchase Risk pada produk perluasan merek}

Hasil pengujian yang dilakukan menunjukkan bahwa terdapat perbedaan perception of purchase risk yang dirasakan oleh konsumen berdasarkan brand familiarity. Perception of purchase risk yang dirasakan oleh konsumen akan semakin rendah ketika merek yang melakukan perluasan adalah merek yang familiar dibandingkan dengan unfamiliar. Hasil hipotesis ini sejalan dengan pernyataan yang diungkapkan oleh Thamaraiselvan dan Raja (2008) bahwa sebuah merek yang sudah dikenal baik akan bertindak sebagai pengurang risiko dan meningkatkan kemungkinan dari mencoba pembelian produk baru. Selain itu, hal ini didukung dengan pernyataan dari Keller (2008) tentang manfaat penggunaan strategi brand extension yaitu mengurangi persepsi risiko dari pelanggan yang mana salah satu faktor yang penting untuk memprediksi peluncuran dari produk brand extension adalah hubungan pelanggan dengan family brand. Pelanggan yang sudah dekat dengan merek dari suatu perusahaan tertentu akan dengan mudah 
dikomunikasikan karena perusahaan tersebut identik dengan lamanya perusahaan itu eksis di pasar dan bertahan dalam persaingan.

\section{Hubungan interaksi antara dukungan endorser dan brand familiarity terhadap Perception of purchase riskpada produk perluasan merek}

Hasil pengujian yang dilakukan menunjukkan bahwa tidak terdapat efek interaksi antara dukungan endorser dan brand familiarity terhadap perception of purchase risk yang dirasakan oleh konsumen, meskipunjika dilihat dari keempat interaksi tersebut diperoleh hasil bahwa interaksi antara celebrity endorser dan merek yang familiar memiliki nilai terkecil yang artinya interaksi tersebut mampu menurunkan perception of purchase risk lebih banyak dibandingkan dengan interaksi lainnya. Hal ini terjadi karena brand familiarity dinilai memiliki pengaruh yang besar dalam menentukan respon konsumen terhadap kualitas dari produk perluasan. Berdasarkan penelitian yang dilakukan oleh Baker dkk., (1987) mengemukakan bahwa ketika sebuah merek sudah familiar dengan konsumen melalui ekspose yang berulang - ulang maka persepsi risiko yang dirasakan konsumen akan semakin berkurang dan meningkatkan sikap yang baik terhadap produk. Sehingga dapat disimpulkan bahwa merek yang familiar saja sudah cukup untuk menurunkan perception of purchase risk dan adanya penggunaan endorser dalam penelitian ini tidak menimbulkan efek yang besar.

\section{Hubungan Perception of purchase risk terhadap niat beli pada produk perluasan merek}

Hasil dari pengujian yang dilakukan menunjukkan bahwa perception of purchase risk berpengaruh negatif terhadap niat beli pada produk perluasan merek sehingga hipotesis ke empat dalam penelitian ini didukung. Hal ini sejalan dengan pernyataan yang diungkapkan oleh Hem, Leslie dan Iversen (2001) bahwa persepsi risiko merupakan sebuah konstruk multidimensional yang menujukkan bagaimana pengalaman konsumen sebelum melakukan pembelian tentang ketidakpastiannya mengenai tipe dan tingkat kehilangan harapan dari hasil pembelian dan penggunaan produk. Pengalaman serta pengetahuan yang lebih banyak tentang kategori produk akan menurunkan resiko dan biaya kerugian yang dihayati sehingga meningkatkan niat pembelian konsumen atas sebuah produk. Jika konsumen memiliki pengetahuan akan produk, konsumen akan percaya pada produk tersebut selanjutnya akan terbentuk niat beli (Schiffman dan Kanuk, 2007). Berdasarkan pemaparan tersebut dapat diprediksi juga bahwa ketika seseorang konsumen mempersepsikan risiko lebih besar dalam mengevaluasi suatu produk maka niat pembelian tidak akan terjadi (Hadianingtyas, 2013). Sebagai kesimpulannya, konsumen menganggap bahwa pengetahuannya mengenai tipe produk pengharum ruangan dan harapan terhadap produk tersebut tinggi sehingga persepsi risiko yang dirasakan semakin rendah yang akhirnya mempengaruhi niat beli. 


\section{Lialutfi Mayangsari \\ Y. Lilik Rudianto}

\section{SIMPULAN}

1. Tidak terdapat perbedaan pada perception of purchase risk berdasarkan dukungan endorser dimana perception of purchase risk lebih rendah apabila memunculkan dukungan endorser berupa celebrity dibandingkan dengan tanpa dukungan endorser (no endorser).

2. Terdapat perbedaan yang signifikan pada perception of purchase risk berdasarkan dukungan endorser dimana perception of purchase risk lebih rendah apabila memunculkan merek yang familiar dibandingkan merek yang unfamiliar.

3. Tidak terdapat pengaruh interaksi yang signifikan antara dukungan endorser dan brand familiarity dimana interaksi antara celebrity endorser dan merek yang familiar akan menimbulkan perception of purchase risk yang lebih rendah dibandingkan dengan interaksi lainnya.

4. Perception of purchase risk memiliki pengaruh negatif secara signifikan dengan niat beli pada produk perluasan merek.

\section{REFERENSI}

Aaker, D. A. dan K. L. Keller. 1990. Consumer Evaluations of Brand Extensions. Journal of Marketing, 54:27-41.

Alba, J. W. dan J. W. Hutchinson. 1987. Dimensions of Consumer Expertise. Journal of Consumer Research, 13(4):41 1-454.

Baker, W. Hutchinson, J. W., Moore, D. dan Nedungadi, P. 1986. Brand Familiarity and Advertising: Effects on the Evoked Set and Brand Preference. Advances in Consumer Research, 13(1): 637-642.

Belch, G. E. dan M. A. Belch. 2004. Advertising and Promotions: an Integrated Marketing Communications Perspective. Sixth Edition. New York: McGraw-Hill Inc.

Belch, G. E dan M. A. Belch. 2012. An Integrated Marketing Communication Perspective. 9th Edition. USA: Mc Graw Hill.

Biswas, D., A. Biswas dan N. Das. 2006. The Differential Effects of Celebrity and Expert Endorsments on Consumer Risk Perception: The Role of Consumer Knowledge, Percieved Congruency, and Product Technology Orientation. Journal of Advertising, Vol. 35(2), 17-31.

Boush, D. M. dan B. Loken. 1991. A Process Tracing Study of Brand Extension Evaluation. Journal of Marketing Research,28:16-28. 
Choi, S. M. dan N. J. Rifon. 2007. Who is The Celebrity in Advertising? Understanding Dimensions of Celebrity Images. Journal of Popular Culture, 40(2):304-25.

Erfgen, C., H. Sattler dan O. Schnittka. 2014. How Celebrity Endorsers Enhance Parent Brand Extendibility to Low Similarity Brand Extensions. Journal of Business Economic.

Goldsmith, R. E., Lafferty dan S. J. Newell. 2000. The Impact of Corporate Credibility and Celebrity Credibility on Consumer Reaction to Advertisements and Brands.Journal of Advertising, 29:4354.

Hadianingtyas, D. S. 2013. Pengaruh faktor keamanan dan persepsi risiko terhadap kepercayaan dan niat beli konsumen secara online dengan moderasi level of internet experience. Skripsi tidak diterbitkan. Surabaya : Fakultas Ekonomi dan Bisnis, Universitas Airlangga.

Haig, M. 2003. Brand Failures The Truth About The 100 Biggest Branding Mistakes of All Time. London: Kogan Page.

Heilman, Carrie M., Douglas Bowman dan Gordon P. Wright. 2000. The Evolution of Brand Preferences and Choice Behaviors of Consumers New to a Market.Journal of Marketing Research, 139-55

Hem, L.E. de Chernatomy dan Iversen,N.M. 2001. Factors Influencing Succesful Brand Extension. Journal of Marketing Management, Vol.19.

Hoch, S. J dan Deighton. J. 1989. Managing What Consumer Learn From Experience. Journal of Marketing, Vol:53.

http://bisnisukm.com/

Keller. K. L. 2008. Strategic Brand Management: Building, Measuring, And Managing Brand Equity. Third Edition. New Jersey: Pearson/Prentice Hall.

Kotler, Philip dan Gary Armstrong. 2013. Principles of Marketing. 14th Edition. Pearson Education Limited. 


\section{Lialutfi Mayangsari \\ Y. Lilik Rudianto}

Kotler, Philip dan K.L. Keller. 2009. Manajemen Pemasaran. Terjemahan: Sabran Bob, Jakarta: Erlangga.

Kotler. P. \& K. Keller. 2012. Marketing Management. 14th Edition. New Jersey: Prentice Hall.

Kusumasondjaja, S. 2014. Efektifitas Social Media Advertising: Peran Brand Familiarity dan Kongruensi Endorser. Jurnal Manajemen dan Kewirausahaan, Vol.16 No.1.

Mayangsari, Lia Lutfi dan Y. Lilik Rudianto, 2015. Pengaruh Penggunaan Endorser dan Brand Familiarity Terhadap Perception Of Purchase Risk dan Dampaknya Pada Niat Beli Produk Brand Extension, Program Studi S1 Manajemen Unair, 139.

McCracken, G. 1989. Who Is The Celebrity Endorser? Cultural Foundations of The Endorsement Process. Journal of Consumer Research, 16:310-321.

Sattler, H., F. Vo"lckner., C. Riediger dan C.M. Ringle. 2010. The Impact of Brand Extension Success Drivers on Brand Extension Price Premiums. International Journal of Research Marketing, 27:319-328.

Schiffman, L.G dan Kanuk L.L. 2007. Consumer Behavior. New Jersey : Pearson Education Inc.

Tam, J.L.M. (2008). Brand Familiarity: Its Effect On satisfaction Evaluuations. Journal Of Services marketing,Vol. 22 No. 1, pp. 3-12.

Tamaraiselvan, N dan J. Raja. How Do Consumers Evaluate Brand Extension. Journal of Service Research. Vol. 8 No.1.

Temporal dan K.C. Lee (2001). Hi Tech Hi Touch Branding: Creating Brand Power in The Age of Technology. Singapore: John Wiley and Sons Pte. Ltd.

Yeo, J dan J. Park. 2006. Effects of Parent-Extension Similarity and Self Regulatory Focus on Evaluations of Brand Extensions. Journal of Consumer Psychology, 16:272-282. 
Jurnal Manajemen Teori dan Terapan

Tahun 7. No. 2, Agustus 2014 